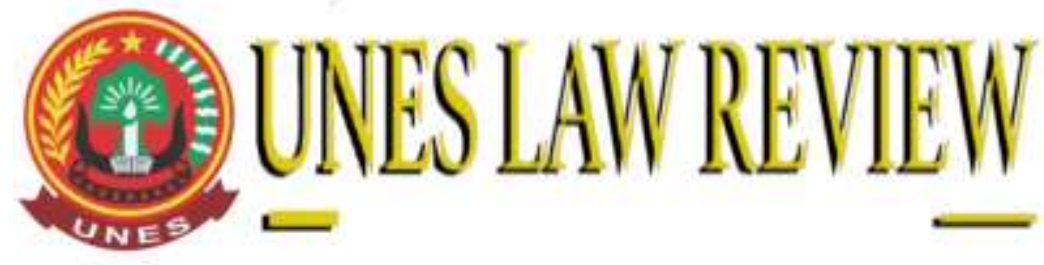

$+6282287504359$

$+6282287504359$

https://review-unes.com/

uneslawreview@gmail.com

DOI: https://doi.org/10.31933/unesrev.v3i3

Diterima: 15/12/2020, Diperbaiki: 24/05/2021, Diterbitkan: 26/05/2021

\title{
ANALISIS YURIDIS TERHADAP ASAS PEMBENTUKAN DAN ASAS MATERI PERATURAN WALIKOTA AMBON TENTANG PEMBATASAN SOSIAL BERSKALA BESAR
}

\author{
${ }^{1)}$ Sherlock. H. Lekipiouw, ${ }^{2)}$ Hendrik Salmo, ${ }^{3)}$ Julista Mustamu, ${ }^{4)}$ Heillen. M. Y. Tita \\ 1)- 4) Universitas Pattimura, Ambon, Maluku, Indonesia \\ Corresponding Author: Sherlock
}

\section{ABSTRACT}

There are several articles in the Ambon Mayor's Regulation Regarding PSSB which do not reflect the formation and regulations of the legislation. The purpose of this research is to study and analyze the implementation as the formation and principle of the material of legislation. The research method used is normative legal research. The results of the study show that the establishment of Ambon Mayor Regulation Number 18 of 2020 concerning the Implementation of Large-Scale Social Restrictions in Handling Corona Virus Disease 2019 (COVID-19) in Ambon City has not reflected as a statutory regulation and the material principle of statutory regulations.

Keywords: Principles of Formation of Legislations, Principles of Material Legislation

\section{ABSTRAK}

Terdapat beberapa Pasal dalam Peraturan Walikota Ambon Mengenai PSSB yang tidak mencerminkan asas pembentukan dan asas materi peraturan perundang- undangan. Tujuan penelitian untuk mengkaji dan menganalisis implementasi asas pembentukan dan asas materi peraturan perundang-undangan. Metode penelitian yang digunakan adalah penelitian hukum normatif. Hasil penelitian menunjukan bahwa pembentukan Peraturan Walikota Ambon Nomor 18 Tahun 2020 Tentang Pelaksanaan Pembatasan Sosial Berskala Besar Dalam Penanganan Corona Virus Disease 2019 (COVID-19) di Kota Ambon belum mencerminkan asas pembentukan peraturan perundang-undangan dan asas meteri peraturan perundang-undangan.

Kata Kunci: Asas Pembentukan Peraturan Perundang - Undangan, Asas Materi Peraturan Perundang - Undangan 


\section{PENDAHULUAN}

Pemerintah Pusat telah menetapkan Pandemi Corona Virus Disease (Covid-19) sebagai Bencana Nasional berdasarkan Keputusan Presdien Nomor 11Tahun 2020 tentang Penetapan Kedaruratan Kesehatan Masyarakat Corona virus Disease 2019 (Covid-19 serta menetapkan Peraturan Pemerintah Nomor 21 Tahun 2020 tentang Pembatasan Sosial Berskala Besar Dalam Rangka Percepatan Penanganan Corona virus Disease 2019 (Covid-19). Pengaturan tersebut ditindak lanjuti oleh sejumlah peraturan teknis ditingkat kementrian dan protokol penanggulangan Covid-19. Berbagai regulasi dan kebijakan tersebut senantiasa ditelaah dan dikaji secara mendalam agar lebih efektif dalam menyelesaikan masalah dan tidak semakin memperburuk keadaan ditengah tengah situasi dan kondisi akbiat pandemi Covid-19 yang berdampak dalam segala aspek kehidupan masyarakat termasuk didalamnya tugas pelayanan publik oleh Pemerintah Daerah di Provinsi Maluku secara umum dan khususnya di Kota Ambon.

Kebijakan pencegahan dan penanggulangan Covid-19 sebagai kosekuensi dari kedaruratan kesehatan masyarakat akibat pandemi Covid-19 haruslah ditempatkan pada perioritas yang utama dalam segala kebijakan pemerintahan. Kebijakan pemerintahan atau kebjakan negara (state policy) dari aspek hukum, untuk mempunyai daya ikat yang bersifat memaksa haruslah dituangkan dalam bentuk hukum tertentu sehingga dapat menjadi dasar legalitas dan legitimasi tindakan hukum pemerintahan serta memberikan jaminan terhadap hak hak dasar dan kedudukan hukum warga negara terhadap pemerintahan (het legaliteits beginsel beoogt de rechtspositie van de burger jegens de overheid te waarborgen). Dengan demikian, setiap perbuatan atau tindakan administrasi harus didasarkan atas aturan atau ' rules and procedures' (regels).

Dengan mempertimbangkan penyebaran Covid-19 yang terus meningkat dari waktu ke waktu dan telah berimplikasi pada semua aspek kehidupan, maka diperlukan upaya percepatan penanggulangan Covid-19 dengan langkah-langkah cepat, fokus, terpadu dan sinergis antar santuan pemerintahan di tingkat daerah yakni antar Pemerintah Provinsi dan Kabupaten/Kota termasuk keterlibat stakeholders dan seluruh lapisan masyarakat. Namun demikian, berdasarkan hasil analisa dan evaluasi dari Kementerian Dalam Negeri bersama Gugus Tugas Percepatan Penanggulangan Covid-19 serta laporan dari Pemerintah Daerah atas penyebaran Covid-19 yang menunjukan adanya peningkatan kurva penyebaran virus dengan peningkatan angka positif terkena virus corona (Covid-19) sebagai akibat belum maksimalnya penerapan protokol kesehatan yang belum secara maksimal sampai ke masyarakat secara masif dan merata.

Provinsi Maluku dengan karateristik wilayah kepualauan dengan gugusan pulau pulau tentunya memiliki kesulitan tingkat geografis juga menjadi salah satu faktor penting dalam upaya penerapan protokol kesehatan secara masif dan merata. Mekanise pengawasan oleh satuan pemerintah disetiap tingkatan baik provinsi, kabupaten dan kota sampai pada tingkat kecamatan, kelurahan, desa hingga ketingakat RT/RW perlu dioptimal dan disinergikan dengan penguatan dan pengerakan sumber daya yang dimiliki.

Dalam upaya pencegahan dan penanggulangan Corona Virus Disease 2019 (Covid-19), Pemerintah Provinsi Maluku telah melakukan berbagai upaya dan kebijakan salah satunya yakni 
menerbitkan Peraturan Gubernur Maluku Nomor 15 Tahun 2020 tentang Pembatasan Pergerakan Orang Dan Moda Transportasi Dalam Penanganan Corona Virus Disease 2019 (Covid-19) Di Pulau Ambon, yang ditetapkan oleh Gubernur Maluku tertanggal 21 April 2020. Selanjutnya Walikota Ambon menetapkan Peraturan Walikota Ambon Nomor 16 Tahun 2020 tentang Pembatasan Kegiatan Orang, Aktifitas Usaha Dan Moda Transportasi Dalam Penanganan Corona Virus Disease 2019 (Covid-19) Di Kota Ambon, tertanggal 3 Juni 2020.

Ditengah pelaksanaan Pembatasan Kegiatan Masyarakat yang dilakukan oleh Pemerintah Kota Ambon, pada tanggal 9 Juni 2020, Menteri Kesehatan menerbitkan Surat Keputusan Nomor HK.01/07/MENKES/358/2020 tentang Penetapan Pembatasan Sosial Berskala Besar Di Wilayah Kota Ambon Provinsi Maluku Dalam Rangka Percepatanan Penanganan Corona Virus Disease 2019 (Covid-19). Keputusan tersebut kemudian ditindaklanjuti oleh Pemerintah Kota Ambon dengan menerbitkan Peraturan Walikota Ambon Nomor 18 Tahun 2020 tentang Pelaksanaan Pembatasan Sosial Berskala Besar Dalam Rangka Penanganan Corona Virus Disease 2019 (Covid-19) Di Kota Ambon, yang ditetapkan oleh Walikota Ambon pada tanggal 19 Juni 2020.

Penerapan PSBB di Kota Ambon melalui Peraturan Walikota Ambon Nomor 18 Tahun 2020, mendapatkan berbagai reaksi dari sebagian kalangan masyarakat termasuk didalamnya juga terkait dengan penerapan Peraturan Walikota Ambon Nomor 16 Tahun 2020 terkait dengan Pembatasan Kegiatan Masyarakat. Selain itu, persoalan rumusan norma dalam Peraturan Walikota Ambon Nomor 18 Tahun 2020 juga perlu mendapat kajian yang mendalam karena dinilai agak bias, tidak efektif dan bahkan dapat menjadi persoalan dalam menunjang pelaksanaan PSBB di Kota Ambon, misalnya dalam rumusan Pasal 1 angka 12 terkait dengan Kosep Karyawan adalah Karyawan/Karyawati/pegawai yang bekerja dalam kantor/ perusahaan/ instansi baik pemerintah maupun swasta.

Selain itu, dalam Pasal 11 ayat (1) mengatur bahwa Institusi pendidikan lainnya yang dilakukan penghentian sementara selama pemberlakuan PSBB sebagaimana dimaksud dalam Pasal 8 ayat (1) meliputi:.......,Ketentuan ini jika dikaitkan dengan Pasal 8 ternyata tidak memiliki keterkaitan, karena Pasal 8 mengatur tentang Kewajiban setiap orang selama pemberlakukan PSBB.

Hal tersebut tentunya tidak sesuai dengan rumusan Pasal 5 huruf e Undang- undang Nomor 12 Tahun 2011 Tentang Pembentukan Peraturan Perundang-undangan yang dalam Penjelasan Pasal menyatakan bahwa yang dimaksud dengan "asas kejelasan rumusan" adalah bahwa setiap Peraturan Perundang-undangan harus memenuhi persyaratan teknis penyusunan Peraturan Perundang-undangan, sistematika, pilihan kata atau istilah, serta bahasa hukum yang jelas dan mudah dimengerti sehingga tidak menimbulkan berbagai macam interpretasi dalam pelaksanaannya.

Menurut Maria Farida dkk (2008:2), bahwa setiap perancang perundang-undangan, baik yang ada pada lembaga legislatif (DPR/DPRD) maupun yang ada pada eksekutif (pemerintah pusat/daerah) berkewajiban memahami hukum perundang-undangan yang berlaku. Penguasaan yang benar atas hukum perundang-undangan akan memberikan kontribusi yang sangat relevan bagi pembentukan hukum. Ketidakcermatan dalam menguasai Hukum Perundang-undangan 
yang berlaku dapat menjadi sebab cacatnya aturan hukum yang dibentuk baik secara formil maupun materiil.

Pasal 5 Undang-undang Nomor 12 Tahun 2011 Tentang Pembentukan Peraturan Perundang-undangan (UU P3) menetapkan bahwa dalam membentuk Peraturan Perundangundangan harus dilakukan berdasarkan pada asas Pembentukan Peraturan Perundang-undangan yang baik, yang meliputi:

a. kejelasan tujuan;

b. kelembagaan atau pejabat pembentuk yang tepat;

c. kesesuaian antara jenis, hierarki, dan materi muatan;

d. dapat dilaksanakan;

e. kedayagunaan dan kehasilgunaan;

f. kejelasan rumusan; dan

g. keterbukaan.

Sementara itu, Pasal 6 ayat (1) UU P3 mengatur bahwa Materi muatan Peraturan Perundang-undangan harus mencerminkan asas:

a. pengayoman;

b. kemanusiaan;

c. kebangsaan;

d. kekeluargaan;

e. kenusantaraan;

f. bhinneka tunggal ika;

g. keadilan;

h. kesamaan kedudukan dalam hukum dan pemerintahan;

i. ketertiban dan kepastian hukum; dan/atau

j. keseimbangan, keserasian, dan keselarasan.

Berdasarkan hal tersebut dapat diketahui bahwa dalam penyusunan suatu produk hukum terdapat asas maupun kaedah yang menjadi penuntun dalam pembentukannya, tetapi dalam pembentukan Perwali PSBB Kota Ambon masih terdapat beberapa rumusan norma yang kontradiktif dengan asas pembentukan Peraturan perundang-undangan yang diatur dalam UU P3. Untuk itu, dalam kerangka pembentukan suatu peraturan perundang-undangan, dan melakukan kajian akademik terhadap keberadaan Peraturan Walikota Ambon Nomor 18 Tahun 2020. Kajian akademik ini memfokuskan pada telahan dan analisis terhadap kerangka peraturan walikota dan untuk memberikan tanggapan dan solusi alternatif sebagai bahan masukan bagi Pemerintah Kota dalam memutus mata rantai penyebaran Corana Virus Disease 2019 (Cvoid-19) sehingga proses pemulihan menuju kepada tatanan kehidupan baru (New Normal) dapat diwujudkan.

Berdasarkan hal tersebut maka fokus analisis dan menjadi legal issue yakni terkait dengan aspek subtansial dan aspek prosedural dalam pembentukan produk hukum sesuai dengan asas dan kaidah hukum dalam penyusunan materi muatan suatu peraturan perundang undangan dalam hal ini terkait dengan implementasi asas pembentukan peraturan perundang-undangan dalam Peraturan Walikota Ambon Nomor 18 Tahun 2020 tentang PSBB di Kota Ambon. 


\section{METODE PENELITIAN}

Metode penelitian yang digunakan dalam penyusunan kajian ini adalah metode penelitian hukum doktriner atau normatif. Metode ini digunakan untuk melakukan analisis tekstual terkait dengan peraturan perundang undangan yang terkait dengan subtansi materi muatan dalam Peraturan Walikota Ambon Nomor 18 Tahun 2020 yang kemudian dikaji dan dianalisis dan dijelaskan dalam konstruksi perumusan norma dalam bentuk sandingan materi muatan. Selanjutnya, dilakukan rangkaian tahapan kajian akademik sebagaimana dimaksud dalam ketentuan Pasal 56 ayat (2) dan Pasal 80 Undang-Undang Nomor 12 Tahun 2011 juncto Undang Undang Nomor 15 Tahun 2019 serta Permendagri Nomor 120 Tahun 2018 tentang Perbuahan Atas Permendagri Nomor 80 Tahun 2015 tentang Pembentukan Produk Hukum Daerah.

\section{HASIL DAN PEMBAHASAN}

\section{Implementasi asas pembentukan peraturan perundang-undangan dalam Perwali PSBB Kota Ambon}

Pembentukan peraturan perundang-undangan dalam sebuah negara hukum yang demokrasi tidak lagi semata-mata menjadi wilayah dominasi eksekutif (birokrat) dan parlemen, namun juga sudah menjadi bagian dari tanggung jawab masyarakat untuk berpartisipasi di dalamnya. Sebagai subjek yang akan menerima dampak keberlakukan peraturan perundangundangan, masyarakat ikut menentukan arah kebijakan Prioritas Penyusunan Peraturan Perundang-Undangan, tanpa keterlibatan masyarakat dalam pembentukannya, mustahil sebuah peraturan perundang-undangan tersebut dapat diterima dan dilaksanakan dengan baik (Yuliandri dkk, 2014:6). Dengan demikian, suatu produk hukum tersebut lahir bukan sekedar memenuhi kehendak dari penguasa untuk melegitimasikan kekuasaannya, melainkan untuk kepentingan pengelolaan kehidupan bernegara yang lebih besat. Di mana, peraturan perundang-undangan dibuat untuk keperluan memenuhi kebutuhan hidup masyarakat.

Dalam kaitan dengan hal tersebut, maka Peraturan Walikota Nomor 18 Tahun 2020 tentang Pemberlakuan Pembatasan Sosial Berskala Besar Dalam Penanganan Corona Virus Disease 2019 (Covis-19) Di kota Ambon, terdiri dari:

a) 11 (sebelas) BAB, yang terdiri dari Ketentuan Umum, Maksud dan Tujuan, Ruang Lingkup, Pelaksanaan PSBB, Hak dan Kewajiban Serta Pemenuhan Kebutuhan Dasar Penduduk Selama Pembatasan, Sumber Daya Penanganan Corona Virus Disease 2019 (Covid-19), Pemantauan, Evaluasi dan Pelaporan, Sumber Pendanaan, Sanksi, Ketentuan Lain Lain dan Penutup; dan

b) 84 (delapan puluh empat) Pasal.

Asas pembentukan peraturan perundang-undangan secara normative diatur dalam Pasal 5 UU Nomor 12 Tahun 2011 tentang Pembentukan Peraturan perundang- undangan bahwa dalam membentuk peraturan perundang-undangan harus dilakukan berdasarkan pada asas pembentukan peraturan perundang-undangan yang baik, yang meliputi:

a) asas kejelasan tujuan adalah bahwa setiap Pembentukan Peraturan Perundang-undangan harus mempunyai tujuan yang jelas yang hendak dicapai. 
b) asas kelembagaan atau pejabat pembentuk yang tepat adalah bahwa setiap jenis Peraturan Perundang-undangan harus dibuat oleh lembaga negara atau pejabat Pembentuk Peraturan Perundang-undangan yang berwenang. Peraturan Perundang-undangan tersebut dapat dibatalkan atau batal demi hukum apabila dibuat oleh lembaga negara atau pejabat yang tidak berwenang.

c) asas kesesuaian antara jenis, hierarki, dan materi muatan adalah bahwa dalam Pembentukan Peraturan Perundang-undangan harus benar-benar memperhatikan materi muatan yang tepat sesuai dengan jenis dan hierarki Peraturan Perundang-undangan.

d) asas dapat dilaksanakan adalah bahwa setiap Pembentukan Peraturan Perundang-undangan harus memperhitungkan efektivitas Peraturan Perundang-undangan tersebut di dalam masyarakat, baik secara filosofis, sosiologis, maupun yuridis.

e) asas kedayagunaan dan kehasilgunaan adalah bahwa setiap Peraturan Perundang-undangan dibuat karena memang benar-benar dibutuhkan dan bermanfaat dalam mengatur kehidupan bermasyarakat, berbangsa, dan bernegara.

f) asas kejelasan rumusan adalah bahwa setiap Peraturan Perundang- undangan harus memenuhi persyaratan teknis penyusunan Peraturan Perundang-undangan, sistematika, pilihan kata atau istilah, serta bahasa hukum yang jelas dan mudah dimengerti sehingga tidak menimbulkan berbagai macam interpretasi dalam pelaksanaannya.

g) asas keterbukaan adalah bahwa dalam Pembentukan Peraturan Perundang-undangan mulai dari perencanaan, penyusunan, pembahasan, pengesahan atau penetapan, dan pengundangan bersifat transparan dan terbuka. Dengan demikian, seluruh lapisan masyarakat mempunyai kesempatan yang seluas-luasnya untuk memberikan masukan dalam Pembentukan Peraturan Perundang-undangan.

Berdasarkan hasil kajian dan analisis terhadap materi muatan Peraturan Walikota Ambon Nomor 18 Tahun 2020 terdapat beberapa materi muatan yang seyogyanya dilakukan penyesuaian dan/atau perbaikan sesuai dengan kaidah serta teknis penyusunan suatu peraturan (produk hukum daerah) serta hal hal teknis lainnya, yang antara lain :

Dalam rumusan Pasal 1 angka 12 terkait dengan Kosep Karyawan adalah Karyawan/Karyawati/pegawai yang bekerja dalam kantor/perusahaan/instansi baik pemerintah maupun swasta. Ketentuan ini tidak sesuai dengan Pasal 5 huruf c UU Nomor 12 Tahun 2011 yang mengatur mengenai asas kesesuaian antara jenis, hierarki, dan materi muatan adalah bahwa dalam Pembentukan Peraturan Perundang- undangan harus benar-benar memperhatikan materi muatan yang tepat sesuai dengan jenis dan hierarki Peraturan Perundang-undangan.

Dalam kaitan dengan hal tersebut maka Konsep karyawan dalam rumusan Pasal 1 angka 12 Peraturan Walikota Nomor 18 Tahun 2020 tentang Pemberlakuan Pembatasan Sosial Berskala Besar Dalam Penanganan Corona Virus Disease 2019 (Covis-19) Di kota Ambon perlu ditinjau ulang karena konsep karyawan tidak dikenal maupun tidak relevan dalam rumusan peraturan perundang-undangan, baik itu dalam Undang-Undang Aparatur Sipil Negara maupun rumusan Undang-Undang Ketenagakerjaan, sehingga perlu dikaji apakah perlu menggunakan konsep karyawan/Karyawati/pegawai yang bekerja dalam kantor/perusahaan/instansi baik 
pemerintah maupun swasta ataukah konsep Pekerja/Buruh atau Aparatur Sipil Negra/Pegawai Negeri Sipil/Pegawai Pemerintah dengan Perjanjian kerja.

Selain itu, dalam Pasal 11 ayat (1) mengatur bahwa Institusi pendidikan lainnya yang dilakukan penghentian sementara selama pemberlakuan PSBB sebagaimana dimaksud dalam Pasal 8 ayat (1) meliputi:....Ketentuan ini jika dikaitkan dengan Pasal 8 ayat (1) ternyata tidak memiliki keterkaitan, karena Pasal 8 mengatur tentang Kewajiban setiap orang selama pemberlakukan PSBB.

Dengan demikian dapat diketahui bahwa tidak ada keterkaitan antara Pasal 11 ayat (1) dengan Pasal 8 ayat (1) hal ini menunjukan bahwa kedua Pasal tersebut tidak mencerminkan asas asas kejelasan rumusan adalah bahwa setiap Peraturan Perundang-undangan harus memenuhi persyaratan teknis penyusunan Peraturan Perundang-undangan, sistematika, pilihan kata atau istilah, serta bahasa hukum yang jelas dan mudah dimengerti sehingga tidak menimbulkan berbagai macam interpretasi dalam pelaksanaannya sebagaimana Pasal 5 huruf f UU Nomor 12 Tahun 2011.

\section{Implementasi asas materi peraturan perundang-undangan dalam Perwali PSBB Kota Ambon}

Pasal 6 Undang-Undang Nomor 12 Tahun 2011 mengatur mengenai materi muatan peraturan perundang-undangan harus mencerminkan asas:

a) asas pengayoman adalah bahwa setiap Materi Muatan Peraturan Perundang-undangan harus berfungsi memberikan pelindungan untuk menciptakan ketentraman masyarakat.

b) asas kemanusiaan" adalah bahwa setiap Materi Muatan Peraturan Perundang-undangan harus mencerminkan pelindungan dan penghormatan hak asasi manusia serta harkat dan martabat setiap warga negara dan penduduk Indonesia secara proporsional.

c) asas kebangsaan adalah bahwa setiap Materi Muatan Peraturan Perundang-undangan harus mencerminkan sifat dan watak bangsa Indonesia yang majemuk dengan tetap menjaga prinsip Negara Kesatuan Republik Indonesia.

d) asas kekeluargaan adalah bahwa setiap Materi Muatan Peraturan Perundang-undangan harus mencerminkan musyawarah untuk mencapai mufakat dalam setiap pengambilan keputusan.

e) asas kenusantaraan adalah bahwa setiap Materi Muatan Peraturan Perundang-undangan senantiasa memperhatikan kepentingan seluruh wilayah Indonesia dan Materi Muatan Peraturan Perundang-undangan yang dibuat di daerah merupakan bagian dari sistem hukum nasional yang berdasarkan Pancasila dan Undang-Undang Dasar Negara Republik Indonesia Tahun 1945.

f) asas bhinneka tunggal ika adalah bahwa Materi Muatan Peraturan Perundang-undangan harus memperhatikan keragaman penduduk, agama, suku dan golongan, kondisi khusus daerah serta budaya dalam kehidupan bermasyarakat, berbangsa, dan bernegara.

g) asas keadilan adalah bahwa setiap Materi Muatan Peraturan Perundang- undangan harus mencerminkan keadilan secara proporsional bagi setiap warga negara. 
h) asas kesamaan kedudukan dalam hukum dan pemerintahan adalah bahwa setiap Materi Muatan Peraturan Perundang-undangan tidak boleh memuat hal yang bersifat membedakan berdasarkan latar belakang, antara lain, agama, suku, ras, golongan, gender, atau status sosial.

i) asas ketertiban dan kepastian hukum adalah bahwa setiap Materi Muatan Peraturan Perundang-undangan harus dapat mewujudkan ketertiban dalam masyarakat melalui jaminan kepastian hukum.

j) asas keseimbangan, keserasian, dan keselarasan adalah bahwa setiap Materi Muatan Peraturan Perundang-undangan harus mencerminkan keseimbangan, keserasian, dan keselarasan, antara kepentingan individu, masyarakat dan kepentingan bangsa dan negara.

Secara subtansial materi muatan dalam pengaturan pelaksanaan dan/atau pemberlakuan Pembatasan Sosial Berskala Besar (PSBB) baik yang dilakukan oleh Provinsi maupun Kabupaten/Kota memiliki beberapa ketetentuan yang sama atau berlaku secara umum dan ada pula pengaturan yang khusus atau berlaku secara khusus sesuai dengan karateristik wilayah dan aspek aspek sosial budaya lainnya sehingga tidak dapat berlaku dan/atau dipraktekkan pada wilayah atau daerah tertentu.

Selanjutnya dalam Pasal 39 Perwali Nomor 18 Tahun 2020 Tentang Pelaksanaan Pembatasan Sosial Berskala Besar Dalam Penanganan Corona Virus Disease 2019 (COVID-19) di Kota Ambon mengatur mengenai denda bagi pedagang, pengendara kendara roda empat baik umum (pasal 52) maupun pribadi (Pasal 55) yang tidak menggunakan masker paling rendah 250. 000 dan paling banyak 500. 000, sementara itu, terhadap pengendara kendaraan roda 2 (dua) yang tidak menggunakan masker dikenakan denda sebesar Rp. 100.000- Rp. 200000.

Hal tersebut tentunya menimbulkan disparitas dalam pemberian sanksi untuk perbuatan yang sama yaitu tidak menggunakan masker, tetapi memiliki aktifitas yang berbeda. menurut penulis hal ini tidak sesuai dengan Pasal 6 huruf g UU Nomor 12 Tahun 2011 yang mengatur mengenai asas keadilan, yang menjelaskan bahwa asas keadilan adalah bahwa setiap Materi Muatan Peraturan Perundang-undangan harus mencerminkan keadilan secara proporsional bagi setiap warga negara.

Aristoteles menekankan teorinya pada perimbangan atau proporsi, dengan membedakan keadilan menjadi keadilan distributif dan keadilan komutatif. Keadilan distributif adalah keadilan yang menuntut bahwa setiap orang mendapat apa yang menjadi haknya, jadi sifatnya proporsional. Di sini yang dinilai adil adalah apabila setiap orang mendapatkan apa yang menjadi haknya secara proporsional. Jadi keadilan distributif berkenaan dengan penentuan hak dan pembagian hak yang adil dalam hubungan antara masyarakat dengan negara, dalam arti apa yang seharusnya diberikan oleh negara kepada warganya.

Dalam kaitan dengan hal tersebut maka tidak tercermin asas keadilan proposional disebabkan adanya disparitas sanksi terhadap perbuatan yang sama dalam Pasal 39, 52 dan 55 Peraturan Walikota Ambon Nomor 18 Tahun 2020 Tentang Pelaksanaan Pembatasan Sosial Berskala Besar Dalam Penanganan Corona Virus Disease 2019 (COVID-19) di Kota Ambon. 
Lebih lanjut dalam Peraturan Walikota (Perwali) Nomor 19 Tahun 2020 tentang Perubahan atas Peraturan Walikota Ambon Nomor 18 Tahun 2020 Tentang Pelaksanaan Pembatasan Sosial Berskala Besar Dalam Penanganan Corona Virus Disease 2019 (COVID-19) di Kota Ambon, pada tanggal 6 Juli 2020 tidak melakukan perubahan terhadap Pasal-pasal tersebut. Hal ini menunjukan bahwa penyusunan Peraturan Walikota Ambon Nomor 18 Tahun 2020 Tentang Pelaksanaan Pembatasan Sosial Berskala Besar Dalam Penanganan Corona Virus Disease 2019 (COVID-19) di Kota Ambon dan Peraturan Walikota Nomor 19 Tahun 2020 tentang Perubahan atas Peraturan Walikota Ambon Nomor 18 Tahun 2020 Tentang Pelaksanaan Pembatasan Sosial Berskala Besar Dalam Penanganan Corona Virus Disease 2019 (COVID-19) di Kota Ambon tidak mencerminkan asas pembentukan peraturan perundang-undangan dan asas materi muatan peraturan perundang-undangan.

\section{PENUTUP}

Berdasarkan hasil penelitian, maka kesimpulan yang dapat disampaikan bahwa pembentukan Peraturan Walikota Ambon Nomor 18 Tahun 2020 Tentang Pelaksanaan Pembatasan Sosial Berskala Besar Dalam Penanganan Corona Virus Disease 2019 (COVID-19) di Kota Ambon belem mencerminkan asas pembentukan peraturan perundang-undangan dan asas meteri peraturan perundang-undangan.

\section{DAFTAR PUSTAKA}

A..Hamid Attamimi, 1990, Peranan keputusan Presiden Republik Indonesia Dalam Penyelenggaraan Pemerintahan Negara, Suatu studi analisis mengenai Keputusan Presiden yang berfungsi Pengaturan dalam kurun waktu Pelita I- Pelita IV, Disertasi Universitas Indonesia, Jakarta,

Bander J Nasution, Kajian Filosofis tentang Hukum dan Keadilan Dari Pemikiran Klasik Sampai Dengan Pemikiran Moderen, Makalah

Eka N.A.M Sihombing, Penerapan Asas Pembentukan Peraturan Perundangundangan Formil Dan Materil Dalam Pembentukan Peraturan Daerah, Disertasi, Program Studi Doktor Ilmu Hukum Fakultas Hukum Universitas Sumatera Utara Medan, 2020

Maria Farida dkk, 2008, Laporan Kompendium Bidang Hukum Perundang- Undangan, Departemen Hukum Dan Hak Asasi Manusia RI Badan Pembinaan Hukum Nasional Pusat Penelitian Dan Pengembangan Sistem Hukum Nasional, Jakarta

Tim Peneliti Universitas Hasanuddin, 2009, Esensi dan Urgensitas Peraturan Daerah Dalam Pelaksanaan Otonomi Daerah, Hasil Penelitian, Kerjasama Dewan Perwakilan Daerah Republik Indonesia Dan Universitas Hasanuddin, Makassar

Yuliandri, 2009, Asas-asas Pembentukan Peraturan Perundang-undangan yang baik, gagasan terhadap pembentukan peraturan perundang-undangan berkelanjutan, Rajawali Press, Jakarta

Yuliandri dkk, 2014, Pengkajian Hukum Tentang Partisipasi Masyarakat Dalam Penentuan Arah Kebijakan Prioritas Penyusunan Peraturan Perundang- Undangan, Laporan Akhir, Pusat 
Penelitian Dan Pengembangan Sistem Hukum Nasional Badan Pembinaan Hukum Nasional Kementerian Hukum Dan Hak Asasi Manusia RI, Jakarta 